\title{
A feltaláló jogállása az első magyar szabadalmi törvényben
}

\author{
Szabadalmi jog - jogtörténet - feltaláló - iparjogvédelem - \\ szabadalmi bíróság - licencia
}

A történelem kezdete óta a találmányok, mint az emberi ész szüleményei, a technikai és ipari fejlődés alapvető mozgatórugói voltak. E találmányok azok, amelyek lehetővé tették, hogy újabb és újabb lépéseket tegyünk a civilizációs fejlődés véget nem érő, rögös útján. Ma már természetesnek tűnő használati tárgyak, mint a kerék, dinamó, belső égésű motor vagy egy egyszerű golyóstoll is, a feltalálás időpontjában nemcsak korszakalkotónak számított, de egyúttal hozzájárult a technikai fejlődéshez is. E példákhoz hasonlóan a napjainkban születendő találmányokra unokáink is ugyanolyan természetességgel fognak tekinteni, mint ahogy mi is tekintünk a C-vitaminra vagy a tüzhely melletti gyufára. A keréktől az atomreaktoron keresztül a legmodernebb gyógyszerészeti eljárásokkal bezárólag valamennyi korszak valamennyi találmányában közös, hogy azok az ember alkotó tevékenységének eredményei.

\section{A „true and first inventor” alkalmazása az 1895:XXXVII. törvénycikkben}

A modern szabadalmi rendszerek az oltalom odaítélését objektív kritériumoknak való megfeleléstől teszik függővé. ${ }^{1} \mathrm{E}$ tárgyi feltételek vizsgálata tehát arra irányul, hogy a bejelentés tárgya szabadalmazható-e. ${ }^{2}$ Nyilvánvaló, hogy az oltalom elnyerése szempontjából a bejelentés tárgyán volt a hangsúly, azonban az oltalomnak volt egy alanyi oldala is, melyet a jogalkotónak értékelnie kellett. Nem lehet ugyanis figyelmen kívül hagyni, hogy a szabadalmi oltalom célja a hazai ipar fejlesztése és a feltalálói tevékenység serkentése volt. ${ }^{3}$ Ebből adódóan a második cél csak az által valósulhatott meg, ha a tényleges feltaláló részesült elismerésben. Ugyanakkor szabadalmi eljárásunk a felszólalási rendszert követte, amelyben a hatóság hivatalbóli

* Dr. Papp László egyetemi tanársegéd, Debreceni Egyetem Állam- és Jogtudományi Kar Jogtörténeti Tanszék, papp.laszlo@law.unideb.hu.

1 Vö. Dell’Adamı Rezső: A szabadalmi jog szabályozásának alapelvei, Jogtudományi Közlöny, 19. évfolyam (1884), 42. szám, 329-330.

2 A találmányi szabadalmakról szóló 1895:XXXVII. tc. 1. §-a értelmében ezen tárgyi feltételek a találmányi jelleg, újdonság és ipari értékesíthetőség volt.

3 DeUTSch Izidor: A szabadalomból folyó jogviszonyok. Magyar Jogászegyleti Értekezések 11. kötet, 1. füzet, Budapest, 1894, 10. 
vizsgálódása meglehetősen szük körủ volt, és elsősorban az érdekeltekre volt bízva, hogy felszólalnak-e a szabadalmazás ellen. ${ }^{4}$ Így az oltalom elnyerése iránti eljárás sajátossága és az a nyilvánvaló érdek, hogy a tényleges feltaláló részesüljön oltalomban, egy törvényi vélelem által érvényesült. $E$ vélelem értelmében az első bejelentőröl ellenkező bizonyításig azt kellett vélelmezni, hogy ő a bejelentés tárgyának feltalálója. E vélelem megdönthető volt, így az engedélyezési eljárás során, illetve a megadott szabadalommal szemben egy megsemmisítési per keretében az érintett fél bizonyíthatta, hogy nem a bejelentő, hanem ő a találmány eredeti feltalálója. Mindezekből adódik, hogy a törvényi vélelem nem sérthette a feltalálói érdeket, hiszen a valódi feltaláló, jogainak védelme érdekében már az engedélyezés során is felszólalhatott. Fontos hangsúlyozni, hogy a törvényi vélelem gyakorlati alkalmazása nem irányulhatott az eredeti feltalálói érdek sérelmére.

Mindezeken túl a törvényi vélelem alkalmazásának gyakorlati indoka is volt. Ugyanis nagyon könnyen elképzelhetö, hogy egy adott találmányon egymástól függetlenül, akár egymás tudta nélkül többen is dolgoztak, s önállóan igényeltek szabadalmat. Márpedig egy adott müszaki elképzelésre csak egy szabadalmi oltalom volt adható, így valamilyen rangsort kellett felállítani az egyes feltalálók között. A leglogikusabbnak tünő megoldás a feltalálás időpontja szerinti rangsor. Ezt az elvet követte az USA és Kanada szabadalmi joga is, mely azonban eljárásjogi szempontból meglehetősen ingatag, hiszen a korábbi feltalálás időpontjának bizonyítása rendkívül nehézkes, az legfeljebb tanúkkal, feljegyzésekkel történhetett. ${ }^{5}$ Éppen emiatt nem véletlen, hogy Európa államaiban ez a megoldás nem terjedt el.

A feltalálók közötti rangsor megállapításának másik módja a bejelentés napja szerinti sorrend. E megoldás kétségtelen elönye volt, hogy a bejelentéshez csatolt leírásból és rajzokból kétséget kizáróan megállapítható volt, hogy a találmány azonos-e egy korábbival vagy sem. E második megoldást követte a magyar szabadalmi jog is akkor, amikor az első szabályszerű bejelentőnek vélelmezett feltalálói minőséget tulajdonított. Ebben a megközelítésben tehát a feltalálói minőség megítélése szempontjából a bejelentés időpontját kell alapul venni. Ugyanakkor még ebben a rendszerben is elöfordulhatott, hogy többen egyszerre igényeltek oltalmat a találmányra. Ilyenkor a bejelentők közötti kapcsolatot kellett megvizsgálni. Amennyiben többek közös munkájának eredménye volt a találmány, akkor a bíróság az oltalmat a feltalálók részére együttesen adta meg. Azonban ki kell emelni, hogy ebben az esetben a bíróság a bejelentők jogainak egymás közötti arányát nem állapíthatta meg, hiszen a bíróság előtt kizárólag a találmány szabadalmazása képezhette az eljárás tárgyát, míg a szabadalom tulajdonjogával összefüggő bármely jogkérdés rendes bírósági hatáskörbe tartozott. ${ }^{6}$

4 A felszólalási eljárás értelmében a szabadalmi hatóság hivatalból csak a találmányi jelleget és ipari értékesíthetőséget vizsgálhatta. Amennyiben a találmány ezen kritériumoknak megfelelt, a bíróság közzétételt rendelt el, amely két hónapos határidőt biztosított az érdekeltek számára, hogy a bíróság tudomására hozzanak bármilyen szabadalomgátló körülményt.

5 LADOMÉRI SzMERTNIK István: Egy találmány több feltaláló, Szabadalmi Közlöny, 44. évfolyam (1939), 19. szám, 359.

6 1895:XXXVII. tc. 59. § (1) bekezdés; ScHön Tibor: A szabadalmi jog gyakorlati kézikönyve. Budapest, „Pátria" Irodalmi Vállalat és Nyomdai Részvénytársaság, 1934, 16. 
Összességében azt látjuk, hogy szabadalmi törvényünk azon az általánosan elfogadott elvi megállapításon nyugodott, hogy a valódi feltalálót illethette meg a szabadalom. ${ }^{7}$ Azt azonban, hogy ki volt az első feltaláló, a bíróság nem vizsgálhatta, és nem is lett volna képes annak vizsgálatára, ezért a jogalkotó a fent említett törvényi vélelmet állapította meg. $E$ törvényi vélelem pedig azért nem sérthette a feltalálói érdeket, mert szabadalmi jogunk két intézmény által is biztosította a valódi feltaláló jogvédelmét. Egyrészt ha a bejelentő nyilvánvalóan nem az első feltaláló volt, ${ }^{8}$ azaz a bejelentés más rajzaiból, leírásaiból, mintáiból állt, ${ }^{9}$ akkor a valódi feltaláló felszólalási vagy megsemmisítési eljárásban érvényesíthette igényét. ${ }^{10}$ Másrészt ha többek egymástól függetlenül találták fel az adott dolgot, de csak az egyik fél nyújtott be szabadalmi kérelmet, akkor a másik feltalálót korlátozott terjedelemben előhasználati jog illette meg. Ez utóbbi esetben szabadalmi jogunk elkerülhette azt a csapdát, mely a tényleges első feltalálás időpontjának meghatározásában mutatkozott, továbbá érvényre juttathatta a bejelentési elsőbbség elvét, s nem utolsósorban az elöhasználat által az oltalmat nem kapható feltaláló érdeke sem sérült. ${ }^{11}$

\section{A feltalálót megillető jogok}

A szabadalmi oltalom, mint az állam által adott kizárólagos jog célja az iparfejlesztésen túl a feltalálói tevékenység serkentése volt. Ez tükröződik a feltaláló számára biztosított jogokban is, melyek egy része a feltaláló személyéhez füződő jog, míg más része vagyoni típusú jogosítvány volt. A feltalálói tevékenység serkentése abban is megnyilvánult, hogy a szabadalmazás után a társadalom egésze számára legyen nyilvánvaló, hogy az adott találmány kinek az eszmei szüleménye. Ezt az igényt fejezte ki a feltalálói minőség elismerése iránti igény.

7 Ez az elv lényegében a modern szabadalmi gondolkodás kezdetétöl jelen volt, hiszen már a Statue of Monopolis is tartalmazta a „true and first inventor" formula alkalmazásával. Vö. DutFIELD, Graham: Intellectual Propety Rights and the Life Science Industries: Past, Present and the Future. Chippenham, Wiltshire, Antony Rowe Ltd, 2003, 3.; Csécsy György: A szellemi alkotások jogának fejlödéstörténete. In: MiskolcziBodnár Péter (szerk.): A civilisztika fejlödéstörténete, Miskolc, 2006, 96.; Ezenkívül az első modern szabadalmi törvények, mint az USA 1790. évi szabadalmi törvénye, vagy az 1791. évi francia szabadalmi törvény is ezen az elven nyugodott. Vö. BRown, D. Walter: A brief history of patent legislation in the United States, Washington, 1889., 4.; Guellec, Dominiqe - Pottelsberghe de la Potterie, Bruno van: The Ecconomics of the European Patent System: IP Policy for Innovatin and Competition. Oxford, Oxford University Press, 2007, 21.

8 Deutsch Izidor ezt az esetet egyenesen rosszhiszemü szabadalmazásnak nevezi. Vö. DEUTSCH Izidor: A szabadalmi törvényjavaslat, Magyar Jogászegyleti Értekezések 11. kötet 5. füzet, Budapest, 1895, 201.

9 Vö. 1895:XXXVII. tc. 5. §.

10 LADOMÉRI SzMERTNIK István: A magyar szabadalmi törvény, a hozzátartozó végrehajtási rendelet és az ezeket módositó rendelkezések. Budapest, Pallas Részvénytársaság Nyomdája, 1935, 8.

11 FEKETE Ignác: Szabadalmi jogunk reformja. Budapest, 1884, 24. 


\subsection{A feltaláló személyhez füződő jogai}

A feltalálói minőség nem más, mint a ténylegesen szabadalmazott találmány alapját képező szellemi munka konkrét személyhez rendelése. Ugyanúgy, ahogy elszakíthatatlan vérségi kapcsolat van szülő és gyermeke között, hasonló kapcsolat alakul ki feltaláló és találmánya között is. A feltalált dolog minden egyes sajátossága és jellemzője - amelyek lényegében a szabadalmazás feltételeit jelentették - a feltalálói tevékenységre, a feltaláló szellemi munkájára vezethető vissza. Úgy, ahogy a gyermek is hasonlít szüleire, a találmány is magán hordozza azt a sajátosságot, amely kizárólag annak az eredménye, hogy a dolog az adott feltaláló eszmei munkájának terméke. E feltalálói minőség mint személyhez füződő jog részben a szabadalmi jogon belül, részben pedig általános magánjogi intézmények által volt védve.

Szabadalmi törvényünk rögzítette, hogy az oltalom a feltalálót illette meg, akinek e minőségét a szabadalmi lajstromban is fel kellett tüntetni. ${ }^{12} \mathrm{E}$ rendelkezés különös jelentőséget az alkalmazott találmányok esetén nyert, ahol az oltalom jogosultja a munkáltató volt, de ez nem zárhatta ki a valódi feltaláló ebbéli minőségének feltüntetését. ${ }^{13}$ Érdekes, hogy a hazai jogalkotásunkban kezdetektől meglévő alapelv a nemzetközi integrációban mérsékelt visszhangra talált, és csak az 1934. évi londoni konferencia alkalmával került be a Párizsi Uniós Egyezmény törzsszövegébe. E feltalálói minőség mint személyhez füződő jog szabadalmi rendszerünkben azáltal nyert védelmet, hogy a törvény felszólalási és megsemmisítési jogalapot is biztosított arra az esetre, ha valaki más szellemi alkotását felhasználva, jogosulatlanul jutott oltalomhoz.

\subsubsection{A feltalálói minőség szabadalmi jog körén kívül eső jogvédelme}

A feltaláló személyhez füződő joga tulajdonképpen a feltalálói minőség elismerésében és nyilvánosságra hozatalában testesült meg, amelyet elsősorban a szabadalmi törvény biztosított. Ugyanakkor - tekintettel a feltalálói minőség személyhez füződő jellegére - az is nyilvánvaló, hogy a tárgyalt korszakban a feltalálói minőség kétségbevonása vagy megsértése esetén a jogosult egyéb személyiségvédelmi intézményeket is igénybe vehetett.

A feltalálói minőség elismerésére a tárgyalt korszakban döntően a szabadalmi jogon kívül eső, az általános magánjog részét képező személyiségvédelem körében került sor. A személyiségi jogvédelem döntően objektív szankciókat alkalmazott, mint a jogsértés abbahagyására kötelezés, további jogsértéstöl való eltiltás és ítélet közzététele. Azonban a 19. század végétől kezdődően egyre erőteljesebb volt az az igény, hogy a személyiségi jogsértésből eredő vagyoni és nem vagyoni kár kártérítés címén követelhető legyen. Hazai magánjogunk e lehetőséget a neoabszolutizmus korától magában hordozta, hiszen az Optk. 1293. §-a kár alatt a sértett személyében - ideértve az eszmei javakat is - bekövetkezett kárt is értette, melynél fogva, ha a károkozás szándékos vagy súlyosan gondatlan volt, akkor pénzbeli jóvátételt is le-

1895:XXXVII. tc. 5. §, 41. § (2) bek.

13 LÉvy Béla: A szabadalmi törvény elöadói tervezete. Különlenyomat a Jogtudományi Közlöny 1916. évfolyamából, Budapest, 1916, 14. 
hetett igényelni. ${ }^{14}$ A 20. század első harmadára a személyhez füződő jogok védelmének szubjektív eszközeként a nem vagyoni kártérítés intézménye szolgált, amely az 1928-as Mtj. 107-108. §-aiban önálló szabályozást is nyert.

A személyiségi jogvédelem esetkörén túl egyéb magánjogi tárgyú törvények is védték, még ha csak közvetve is, a feltalálói minőséget. Fontos hangsúlyozni, hogy a szabadalmi jog által biztosított jogvédelem csak a bejelentést követően, illetve már megadott szabadalom esetén volt elérhető. Ebből adódóan a bejelentést megelőzően a feltalálói minőség a szabadalmi törvény által védelemben nem volt részesíthető, azonban a találmány titokban tartásához füződő feltalálói érdek oltalmazható volt. Ez tulajdonképpen nem is a feltaláláshoz, hanem a találmány titkának ismeretéhez füződött, mely a tisztességtelen versenyröl szóló 1923. évi V. tc. (a továbbiakban: Tvt.) rendszerében bírt relevanciával. ${ }^{15}$ A Tvt. 15. §-a értelmében tilos volt a jogellenes módon vagy az üzleti érintkezés során bizalmasan megtudott üzleti vagy üzemi (gyártási) titkot felhasználni. E tilalom megsértése esetén az érintett fél többek között nem vagyoni kártérítéssel is élhetett.

\subsection{A feltaláló vagyoni jogosítványai}

A szabadalmi törvény a személyhez füződő jogok mellett a feltaláló vagyoni jogait is szabályozta. A szellemi tulajdonra vonatkozó elméletek során is szembetűnő, hogy azokat a személyhez füződő és vagyonjogi jelleg harcának periodikus változása jellemzi. E harcban egyik vagy másik jelleg sem kerekedhet teljes mértékben felül, a szabadalmi oltalom kapcsán mégis a vagyonjogi jelleg dominanciáját érezhetjük. Ez a szabadalmi oltalomban benne rejlő, és a kizárólagos hasznosításban megtestesülő vagyoni jellegben mutatkozik meg, mely a feltalálói jogállás kapcsán a törvény szerkesztéséből is szembetünik.

A szabadalmi oltalom a jogosult részére kizárólagos jogot biztosított az iparszerü készítésre, forgalomba hozatalra, továbbá a szabadalmi jog fölötti rendelkezésre. ${ }^{16}$ Szabadalmi törvényünk kifejezetten az átruházás és a használati engedély adásának jogát nevesítette. ${ }^{17}$ Ugyanakkor Hoff György helyesen állapította meg, hogy „a szabadalom feletti szabad rendelkezés lehetősége nem a szabadalmi jogban foglalt külön jogosítvány, hanem az egész jogrendszerünk alapfeltételéül szolgáló és minden személyhez nem kötött vagyonjog tekintetében érvényesülö szabad rendelkezési elv folyománya". ${ }^{18}$ A korabeli magánjogi dogmatikával teljesen összhangban álló felfogás már a törvény eredeti koncepciójában is benne rejlett, hiszen a miniszteri indokolás is megfogalmazta, hogy az oltalom „vagyonnak tekintendő és mint ilyen úgy az örö-

14 Szladits Károly: Az osztrák Polgári Törvénykönyv novella-javaslatáról. Magyar Jogászegyleti Értekezések 37. kötet, 1. füzet, Budapest, 1905, 85.

15 Bővebben Kuncz Ödön - BALÁs P. Elemér: A tisztességtelen verseny: az 1923:5. törvénycikk magyarázata, kieg. a törvényt végrehajtó rendeletekkel. Budapest, Politzer, 1924.

16 TúRY Sándor: A magyar szabadalmi jog kézikönyve. Budapest, Győző Andor Könyvkereskedő Kiadása, 1911, 270.

17 1895:XXXVII. tc. 10. § (2) bek.

18 Hoff György: Szabadalmi jog. Pécs, Az Iparjogvédelmi Egyesület kiadmánya, 1939, 214. 
kösökre megy át, valamint élők közt átruházható”. ${ }^{19}$ Ebböl adódóan a szabadalom az örökösökre átszállt, ${ }^{20}$ illetve arról az élők között rendelkezni lehetett. A szabadalom átruházásáról, illetve használatba adásáról, azaz a licenciáról a törvény meglehetösen szükszavúan rendelkezett. ${ }^{21}$ Ennek oka az lehetett, hogy akár a szabadalom tulajdonjoga, akár az azzal összefüggő kötelmi ügyletek - ideértve a licenciát is - nem kizárólagosan a szabadalmi joghoz kapcsolódtak, így rájuk elsősorban az általános magánjogi szabályok voltak az irányadóak. Ezt támasztja alá az is, hogy az említett kérdések nem a Szabadalmi Bíróság, hanem a rendes bíróságok hatáskörébe tartoztak.

\subsubsection{Elidegenités és megterhelés alakszerüsége a szabadalmi jog körében}

A szabadalmi jog, mint vagyoni értékű jogosítvány, kereskedési forgalom tárgya lehetett, azaz ellenérték fejében adásvételi szerződés által vagy ingyenesen, ajándékozási szerződéssel is átruházható volt. Maga a törvény nem tartalmazott alakszerủ előírást a szabadalom átruházásához, azonban azt szóban elidegeníteni mégsem lehetett. Ennek oka az volt, hogy a szabadalmi jogviszonyok hiteles és érvényes igazolására egyedül a szabadalmi lajstrom mint közhitelü nyilvántartás szolgált. E nyilvántartásba bejegyzés alapjául pedig kizárólag teljes bizonyító erejü magánokirat vagy közokirat szolgálhatott. Ebböl adódóan a szabadalom fennállásával összefüggő bármely jogot vagy igényt csak e nyilvántartás által lehetett igazolni. Ezt támasztotta alá a törvény 41 . § (3) bekezdése is, mely kifejezetten elöírta - a hiteles bizonyítás érdekében - az átruházás lajstromba történő felvezetését. ${ }^{22}$ Ugyanakkor e közhitelü nyilvántartás funkcióját tekintve mégsem volt azonos más, hasonló közhitelủ nyilvántartással, mint pl. a telekkönyvvel. A telekkönyvi rendtartásra vonatkozó szabályok értelmében ingatlanra vonatkozó jog kizárólag telekkönyvi bejegyzéssel jöhetett létre, azaz a bejegyzést konstitutív hatályúnak kellett tekinteni. Ebből adódóan ingatlanra tulajdonjog vagy más korlátolt dologi jog csak telekkönyvi bejegyzéssel volt alapítható. ${ }^{23}$ Ettől eltérően a szabadalmi lajstrom nem rendelkezett ilyen erővel. Ezt magából a törvényszövegböl is ki lehet következtetni. A szabadalmi törvény 41 . § (3) bekezdésének rendelkezése szerint a korábbi átruházás azonban, habár nincs is a

19 Az 1892. évi február hó 18. napjára hirdetett Országgyülés Képviselőházának Irományai, XXIII. kötet 741. szám, Budapest, 1894, 35.

20 Meg kell jegyezni, hogy a törvény 10 . §-a értelmében nemcsak a megadott szabadalom, hanem a szabadalmazás iránti igény is átszállt az örökösökre.

21 Vö. MolnÁR István: Szabadalmi anyagi jogi problémák és megoldási elképzelések közfinanszírozású kutatóhelyeken. Doktori értekezés kézirata. Lezárva: Szeged, 2011. szeptember 15. Forrás: http://doktori.bibl.uszeged.hu/1426/1/Phd2010_v26_2012_02_12.pdf, 137.

22 Az 1895:XXXVII. tc. 41. § (3) bekezdése szerint „A szabadalom tulajdonjogának átruházása harmadik személyekkel szemben csakis az átruházásnak a szabadalmi lajstromba való bevezetése által válik joghatályúvá; a korábbi átruházás azonban, habár nincs is a lajstromba bevezetve, hatályos azzal szemben, a kinek akkor, a midőn a szabadalomra jogot szerzett, a korábbi átruházás megtörténtéről tudomása volt”.

23 ImLING Konrád: Telekkönyvi reformok. Magyar Jogászegyleti Értekezések 25. kötet, Budapest, 1885, 4.; WENCZEL Tivadar: A magyar magánjog rövid áttekintése. Budapest, 1877, 71.; Huf József: $A$ magyar telekkönyvi rendtartás gyakorlati használatra. Budapest, 1898, 11.; REITZER Béla: A telekkönyvi bizalom oltalmának határai, különös tekintettel a kétszeri eladások eseteire és a törvényhozásnak e tekintetben való feladataira. Magyar Jogászegyleti Értekezések 37. kötet, 3. füzet, Budapest, 1908, 143. 
lajstromba bevezetve, az átruházás hatályosságát nem érintette. Mindezekből következik, hogy a szabadalmi jog átszállása független volt annak belajstromozásától, azonban a gyakorlatban a szabadalmi jog átruházását mégis nyomban követte a szabadalmi lajstromba történő felvezetés. Ennek oka az lehetett, hogy lajstromozás hiányában a jogszerző fél attól tarthatott, hogy a szabadalmi jogot átruházó a már elidegenített szabadalmat ismételten eladja, s így a harmadik jóhiszemű szerzővel szemben az eredeti vevő védtelen maradhatott volna.

A szabadalmi jog átruházásának további érdekességét adja a törvény 10. § (2) bekezdésének sajátos szövegezése, amely szerint a tulajdonos a szabadalmat élők között „egészben vagy részben” átruházhatja. Az oltalom részleges átruházása az igénypontok vagy az oltalom idöbeli, illetve területi megosztását jelentette volna. A törvényszöveg nyelvtani értelmezése tehát a szabadalom jogi egységét veszélyeztette volna. Önmagában e tényre hivatkozva Hoff György teljesen elutasította az oltalom részleges átruházását, amely, ha el is fogadható, nyilvánvalóan a törvény önkényes felülírását jelentette volna. ${ }^{24}$ Ettől érdekesebb és összetettebb Kósa Zsigmond álláspontja, aki a törvény pontatlan szövegezését a gyakorlati élet sajátosságaihoz igazította. ${ }^{25}$ Érvelése szerint az oltalmi idő megosztása, azaz meghatározott időtartamra történő átruházás folytán a kikötött idő lejárta után az oltalom visszaszáll az eredeti jogosultra. Mindez pedig nem lehet valódi tulajdonátruházás, hiszen magánjogunk a tulajdonjognak hasonló módon történő korlátozását nem ismerte, így ez akként nem is volt felfogható. Ugyanakkor a birtoklás és a használat meghatározott időtartamra történő átadását szabadalmi jogunk ismerte, mely azonban nem tulajdonátruházásnak, hanem licenciának minősült. Ebből adódóan Kósa érvelése a részleges átruházás kapcsán azért volt megengedőbb, mert abban nem a valódi tulajdonátruházást, hanem csak a licencia egy alakját látta. A Kósa-féle érvelést is figyelembe véve mindezekböl az következik, hogy szabadalmi jogunk az oltalomnak a - klasszikus magánjogi értelemben vett - részleges átruházását nem fogadta el, illetve azt csak egyetlenegy esetre, nevezetesen az eszmei hányadrészek szerinti átruházásra szorította. ${ }^{26}$

A szabadalmi jog átruházásától meg kell különböztetni a szabadalmi jog megterhelését. Azzal, hogy a szabadalmi jogot vagyoni értékü jogként definiáljuk, nemcsak az elidegenítés, hanem a megterhelés kérdéseiben, nevezetesen a haszonélvezet és zálog tárgyaként való értékelésben is állást kell foglalni. ${ }^{27} \mathrm{~A}$ fentebb kifejtettek fényében, ha azt állítjuk, hogy szabadalmi törvényünk az elidegenítés tekintetében pontatlanul fogalmazott, akkor a szabadalmi jog megterhelése kapcsán azt látjuk,

24 Hoff: i. m., 218.

25 KósA Zsigmond: A magyar szabadalmi törvény magyarázata: függelékben a Nemzetközi Unióra vonatkozó, - Ausztriával, a Német Birodalommal, Spanyolországgal kötött nemzetközi szerződésekkel és végrehajtási rendeletekkel. Budapest, 1911, 189-190.

26 Ugyanúgy, ahogyan több jogosultja is lehetett a szabadalomnak, azaz az egész szabadalmi jog eszmei hányadrészek szerint több személyt is megillethetett, ezen személyek a tulajdonátruházás általános szabályai szerint saját tulajdoni hányadukkal szabadon rendelkezhettek. Így abban és csakis abban az esetben beszélhetünk a szabadalom részleges elidegenítéséröl, amikor több jogosult közül az egyik saját tulajdoni hányadának elidegenítéséröl döntött.

27 Zálogjog vagyoni értékű jogokon is fennállhatott. Vö. WENCZEL Tivadar: i. m., 93. 
hogy e vonatkozásban gyakorlatilag releváns rendelkezést nem tartalmazott. Véleményem szerint ebből adódott, hogy a Szabadalmi Bíróság hosszú időn keresztül elzárkózott a zálogjog és a haszonélvezet lajstromozásától annak okán, hogy a szabadalmi lajstromban pusztán „a tulajdon és annak változásai nyernek feljegyzést”. ${ }^{28}$ A tárgyalt korszakban ez a merev álláspont fokozatosan enyhült azzal, hogy a licenciát, ${ }^{29}$ majd pedig a szabadalmi kényszerengedélyt ${ }^{30}$ kötelezően be kellett lajstromoztatni annak ellenére, hogy azok a tulajdonjogban változást nem idéztek elő. Ez az enyhülés nyomon követhető a lajstrombetétlapok „feljegyzés” rovatának fokozatos bővítésén. Az 1930-as évek közepétöl kezdve ugyanis ezen rovatban bejegyzés alapjául szolgáló olyan jogcímeket is találunk, mint perfeljegyzés, végrehajtás, elöhasználati jog, zálogjog.

\subsubsection{Licenciaszerződések a szabadalmi jog terén}

A feltaláló vagyoni jogosítványai közül eddig csak az elidegenítésről és megterhelésről esett szó. A szabadalom tulajdonjogának az átruházásától szabadalmi jogunk élesen megkülönböztette a szabadalom gyakorlatbavételének vagy használatbavételének az időleges átruházását, azaz a licenciát. ${ }^{31} \mathrm{~A}$ licencia, amely a szabadalom használatára vonatkozó engedély, már első szabadalmi törvényünk keletkezésének idején sem volt új jelenség a hazai jogalkotásban. Korábban az 1822. évi helytartótanácsi rendelet már lehetővé tette, hogy a jogosult „a neki adott kedvezményeket bérbe adja”. ${ }^{32}$ Ezt követően az 1843. évi tervezet is ismerte a biztosítvány, azaz az oltalom használatának felosztását, ${ }^{33}$ vagyis lehetővé tette, hogy a jogosult a használat jogát harmadik személy részére átengedje. ${ }^{34}$ Ugyanez a szemlélet öröklődött tovább az 1852. évi szabályozásban, amely egyenesen nevesítve, haszonbérbe adásról rendelkezett. ${ }^{35}$

Mindezekböl látható, hogy már a 19. századi szabadalmi gondolkodásban is benne rejlett a szabadalom használatának az átengedése, azonban a fent említett forráshelyekböl is látszik, hogy az nem kifejezetten a licenciában, hanem sokkal inkább használati jogot átruházó jogcímekben, illetve szerződésekben nyilvánult meg. ${ }^{36} \mathrm{~Eb}-$ ből adódóan a 19. század végén is uralkodó felfogás volt, hogy a használati jog átengedése, azaz a licencia nem önálló ügyletfajta, hanem sokkal inkább egy sajátos szolgáltatás, amely többféle ügylethez kapcsolódhat. A leggyakoribb eset az volt, amikor a jogosult a használati jogosítványok gyakorlását teljes mértékben átengedte, s ennek fejében pénzbeli ellenszolgáltatásban részesült. Ebben a megközelítésben

${ }_{28}$ Magyar Országos Levéltár (a továbbiakban: MOL) Polgári kori kormányhatósági levéltárak K szekció (a továbbiakban: K) Iparügyi minisztériumi levéltár (a továbbiakban: 603), 1696. cs. S. 11817(ügyszám)/1931.

29 1895:XXXVII. tc. 41. § (1) bek. 2. fordulat.

30 1932:XVII. tc. 7. §.

31 1895:XXXVII. tc. 10. § (2) bek.

32 1822. évi helytartótanácsi rendelet $\mathrm{V}$. cikk.

33 1843. évi javaslat 58 . §.

${ }^{34}$ A tervezet a jogosult részére pusztán annyit írt elö, hogy a használat átengedését a Helytartótanácsnak be kellett jelentenie.

35 1852. évi helytartótanácsi rendelet 22. §.

36 Wenczel Tivadar: i. m., 112-113. 
a kizárólagos jog gyakorlásának az átengedése önmagában nemcsak egy vagyoni értékű jog gyakorlásának az átengedését jelentette, hanem egy hasznot hajtó, azaz gyümölcsöző jog gyakorlásának az átengedését is, pénzbeli ellenszolgáltatás fejében. Egy gyümölcsöző dolog vagy jog időleges használatának pénzbeli ellenszolgáltatás fejében történő átengedése pedig a korabeli magánjogi felfogásunk alapján haszonbérletnek minősült. Mindezek következményeként a licencia a 19. század végi magánjogi gondolkodásban kötelmi jogi szempontból haszonbérleti szerződésként jelentkezett.

Álláspontom szerint ez lehetett az oka annak, hogy szabadalmi törvényünk a licenciaszerződés formai és tartalmi követelményeiröl gyakorlatilag nem is rendelkezett. A használati jogok átengedésének kérdése a törvény országgyülési vitáján is háttérbe szorult, hiszen egyetlen érdemi hozzászólás sem hangzott el a kérdésben, és egyedül az igazságügyi bizottság módosító javaslatának köszönhető, hogy a használati jog átengedésére vonatkozóan az egyetlen kógens szabály rögzítésre került. Így a licenciaszerződésre vonatkozó egyetlen törvényi rendelkezés a 10. § (2) bekezdésébe került be a következő tartalommal: „a gyakorlatbavételre vagy használatra jogosított e jogát élők közt másra csak akkor ruházhatja át, ha a szabadalom tulajdonosával létrejött megállapodás szerint ez kifejezetten meg van engedve". A későbbi szabadalmi törvénytervezetek sem tartalmaztak eltérö rendelkezést, és az 1916. évi javaslat is csak annyival egészítette ki a meglévő szabályozást, hogy a szabadalom tulajdonosának a személyében bekövetkező változás az átengedési szerződést, azaz a licenciát nem érinti. ${ }^{37}$

Véleményem szerint emiatt juthatott Molnár István arra a megállapításra, hogy a „századfordulón e témában [licenciaszerződés] sem jelentős számú jogeset sem pedig kodifikációs aktus nem volt" ${ }^{38} \mathrm{~A}$ haszonbérlet joganyagának a licenciára történő alkalmazása a tárgyalt korszakban végig jelen volt, melyet az Mtj. szövegezése tovább erősített. Ennek hatásaként 1928-ban a Szabadalmi Bíróság kifejezetten ki is jelentette, hogy „a licenszia engedélyezése a kötelmi jognak a haszonbérleti szerződésre vonatkozó szabályai szerint történik, mert a szabadalom tulajdonosa, tulajdonjogából folyó és a 8. §-ában felsorolt jogositványok bármelyikének gyakorlását (használatát) ellenérték fejében engedi át" ${ }^{39} \mathrm{Ez}$ az ítélet kifejezetten rögzíti azt is, hogy a licenciaszerződéseknél a kötelmi jog haszonbérletre vonatkozó szabályait kell alkalmazni. Ez volt az oka annak, hogy a haszonbérleti joganyag árnyékában fejlődő licenciaszerződésekre kifejezett törvényi rendelkezést nem találunk. Ezért, bár Mezei Péter és Molnár István helyesen állapították meg, ${ }^{40}$ hogy a korai licenciaszerződések vonatkozásában olyan kulcsfontosságú kérdésben, mint a szavatosság, kifejezett törvényi rendelkezés nem volt, a kifejtettek fényében mindez nem jelentette azt, hogy más szavatossági szabályok ne lettek volna felhívhatók. ${ }^{41}$

37 SChuster Rudolf: Az új szabadalmi törvényjavaslat előadói tervezete, Jogtudományi Közlöny, 50. évfolyam (1916), 13. szám, 114.

38 MolnáR István: i. m., 137.

39 MOL K 603 1972. cs. T. 3930/1927

40 Molnár István - Mezel Péter: Szavatosság és termékfelelősség a licensziaszerződésben az egyetem mint licensziaadó szemszögéből, Iparjogvédelmi és Szerzői Jogi Szemle, 115. évfolyam (2010), 1. szám, 28.

41 Vö. Hoff: i. m., 220. 


\section{A feltalálót terhelő kötelezettségek}

A szabadalmi oltalommal együtt járó kizárólagos jog ellentételezéseként szabadalmi jogunk mindössze két kötelezettséget állapított meg a feltaláló irányában. E kötelezettségek közül az első a feltalálót terhelő dífizetési kötelezettség, a másik pedig a gyakorlatba- vagy más szóval használatbavétel kötelezettsége. ${ }^{42}$

\subsection{Díjfizetés mint a feltalálót terhelő kötelezettség}

A szabadalmi eljárással, illetve az oltalom fenntartásával összefüggő díjak jogi természetük szerint kétfélék lehettek. Egyrészt a szabadalmi jogszolgáltatással öszszefüggő adminisztratív és peres eljárások során - mint bármely más közigazgatási vagy bírósági eljárás kapcsán - illetékfizetési kötelezettség keletkezett. ${ }^{43}$ Ezen illetéktöl jogi természetében különbözött a szabadalmak után fizetendő évi díj, amelyröl Harausz Gyula és Perlmutter Alfréd helyesen állapították meg, hogy azok sokkal inkább adó-természetủek. ${ }^{4}$ Ugyanis a szabadalmak után fizetendő díj, az illetékkel ellentétben olyan adótermészetủ szolgáltatás, amelyet a szabadalom tulajdonosa a szabadalomból eredő jogainak védelméért fizetett.

A szabadalmak után fizetendő dijat mégsem lehet egyértelműen adónak tekinteni, ugyanis az adó jellegzetessége annak járulékos jogi természete, azaz az adóalaphoz történő tapadása. Jelen esetben az adóalap a szabadalom tényleges értéke lehetett volna, amelyet azonban nem lehetett meghatározni, továbbá a díjfizetési kötelezettség sem ez alapján, hanem elöre meghatározott díjlétra szerint alakult. Emellett a díjak esedékessége és a nemfizetés következményei is eltérően alakultak az adókéhoz képest.

A szabadalmak után fizetendő dijak lerovását illetően is kétféle rendszer létezett. Az első megoldás szerint a szabadalom egész tartamára vonatkozó díjat egy öszszegben kellett megfizetni. Ezt a rendszert követte az USA és Dánia szabadalmi joga. ${ }^{45} \mathrm{~A}$ legtöbb állam azonban az évenkénti dífizetés elvét követte, amely során a tényleges évi díjmegállapítás ismét kétféle módon történhetett. Vagy évente azonos részleteket kellett fizetni, mint pl. Franciaország, Japán vagy Portugália esetében, vagy az adott évre vonatkozó részlet az idő elörehaladtával progresszív emelkedést

42 LÉvy Béla: A magyar szabadalmi jog rendszere. Budapest, 1898, 88.

43 Illetékfizetési kötelezettség keletkezett a bejelentési kérelem, leírás vagy igénypont módosítására irányuló kérelem, illetve minden egyéb nyilatkozat benyújtása kapcsán. Ezen illetékeket, amelyek döntően az engedélyezési eljáráshoz, tehát a jogszolgáltatás adminisztratív részéhez kapcsolódtak, okmánybélyegben kellett leróni. Hasonlóan illetékfizetési kötelezettség keletkezett a peres beadványok kapcsán is, mint pl. a szabadalmi perek keresetlevelei, fellebbezés, felfolyamodás kapcsán, amelyeket törvénykezési illetékbélyeggel kellett leróni.

44 Perlmutter Alfréd: A találmányok szabadalmazása után fizetendő díjakról, Szabadalmi Közlöny, 20. évfolyam (1915), 756-758.; HaRAuSz Gyula: Az évi díjakról a magyar szabadalmi törvényben, Szabadalmi Közlöny, 27. évfolyam (1922), 419.

45 JÁmBor Gyula: Szabadalmi ügyünk reformjához, Magyar Mérnök- és Építész-Egylet Közlönye, 3. füzet (1894), 98.; TöRöK László: A találmányi szabadalom. Budapest, 1913, 94. 
mutatott, mint pl. Németország, Ausztria, Belgium vagy Magyarország vonatkozásában. ${ }^{46}$

A szabadalom iparfejlesztő hatását legjobban az utóbbi megoldás, nevezetesen az évről évre emelkedő díjak szolgálhatják. Ugyanis a kezdeti években a szabadalmi díjak csekély összege nem jelentett túlzott megterhelést a szabadalmasra, majd az idő előrehaladtával, ahogy találmányát ténylegesen értékesíteni tudta, azaz a szabadalomból konkrét anyagi előnyt kovácsolt, a már megemelkedett összeg kifizetése nem jelenthetett gondot. ${ }^{47}$ Továbbá a szabadalmi díjak progresszív emelkedése lehetővé tette, hogy a gazdaságilag értéktelen szabadalmak hosszú időn keresztül ne részesüljenek oltalomban, hiszen ha egy találmány nem váltotta be a hozzá füzött „piaci reményeket”, akkor egy idő után a jogosultnak nem érte meg az oltalom fenntartása. ${ }^{48}$

A szabadalmi díjak eltérnek az adóktól az esedékességükben is. ${ }^{49} \mathrm{~A}$ szabadalmi bejelentés időpontjában nem szabadalmi díjat, hanem bejelentési díjat mint illetéket kellett leróni. Ebben az időpontban a feltalálótól a szabadalmi díj még nem volt követelhető. A bejelentés közzétételével azonban a találmány olyan jogi státuszba került, melyből szabadalom, azaz Harausz Gyula szavaival élve „adóalap” válhatott, mely díffizetési kötelezettséget váltott ki. ${ }^{50}$ Ebből adódóan az első szabadalmi díj esedékessége a közzétételhez igazodott, vagyis a közzététel megtörténtét követő naptól ${ }^{51}$ számított két hónapon belül kellett azt megfizetni. ${ }^{52} \mathrm{~A}$ második és azt követő évre vonatkozó szabadalmi díj pedig a bejelentés iktatási napjának évfordulóján vált esedékessé, azaz ezen időponttól számított 30 napon belül kellett megfizetni. ${ }^{53} \mathrm{E}$ határidő elmulasztása nem minősült jogvesztőnek, ugyanis a 30. nap letelte után, de az esedékessé válástól számított 6 hónapon belül pótdíj ellenében is lehetett teljesíteni. ${ }^{54}$

46 SINGER, Berthold: Patent and trade mark laws of the world. Chicago, 1911, 42, 60, 172.

47 A magyar szabadalmi díjlétra kapcsán a fokozatosság kitűnően megfigyelhető, hiszen az első és 10. évre vonatkozó szabadalmi díj között nyolcszoros, míg az első és 20. évre vonatkozó szabadalmi díj között nyolcvanszoros különbség figyelhető meg.

48 A szabályozás sajátossága, hogy bár az évenkénti dífiizetés a szabadalmas helyzetét könnyítette, azonban ez nem jelentette azt, hogy a díjat egy összegben, vagy akár a több évre vonatkozó díjat egyszerre ne róhatta volna le.

49 Az esedékesség kérdése nyilvánvalóan csak az évenkénti dífiizetés során merülhet fel.

50 Harausz Gyula: i. m., 422.

51 A közzététel megtörténtének tényleges időpontja a Szabadalmi Közlönyben való megjelenés volt. Mindezt azért érdemes kiemelni, mert különbséget kell tenni a közzététel elrendelése és annak tényleges megtörténte között.

52 A határidő elmulasztása esetén a 150.400/1932. K M. rendelet 12. §-a értelmében 15 napon belül a díjfizetés a késedelem egyidejű igazolása mellett pótolható volt. Ezen határidő elmulasztása esetén azonban a Szabadalmi Bíróság a bejelentést visszavontnak tekintette.

53 TÖRÖK László: i. m., 93.

54 A pótdíj sajátossága, hogy annak összege a késedelem időtartamához igazodott. Ugyanis az esedékessé válástól számított második vagy harmadik hónapban történő fizetés esetén a pótdíj összege a szabadalmi díj negyedrészét tette ki, míg a negyedik, ötödik vagy hatodik hónapban történő teljesítés esetén a pótdíj összege a szabadalmi díj összegével volt egyenlő. 
E hat hónapos legutolsó határidő elmulasztása azonban a szabadalom ipso iure megszünését jelentette. ${ }^{55}$

A befizetett évi díjak, illetve illetékek fö szabály szerint nem voltak visszakövetelhetőek, ez alól azonban szabadalmi jogunk több kivételt is megállapított. Vissza kellett utalni a szabadalom jogerős megadása előtt befizetett második és további évekre vonatkozó díjakat, ${ }^{56}$ amennyiben a bíróság a díjak befizetése után a szabadalmat megtagadta. ${ }^{57}$ Ugyanezen oknál fogva vissza kellett utalni azokat az elöre befizetett évi díjakat is, amelyeknek esedékessé válása előtt az oltalom bármely okból megszünt. ${ }^{58}$ Ugyanakkor a díjvisszafizetés szempontjából nem volt mindegy, hogy az oltalom megtagadás vagy a közzétett bejelentés visszavonása folytán maradt el..$^{59}$ Bár a törvény 37 . $§(3)$ bekezdése a megtagadáshoz és visszavonáshoz ugyanazt a jogkövetkezményt füzte, de utóbbi esetben a díj nem járt vissza. ${ }^{60}$ Ennek oka abban keresendő, hogy a bejelentés közzététele esetén egy törvényi vélelem állt fenn a találmány szabadalmazhatósága kapcsán, amely az ideiglenes oltalomban nyilvánult meg. A törvény 45 . $§(3)$ bekezdése ${ }^{61}$ értelmében a szabadalmi díjat az igénybevett oltalmi időre tekintettel kellett megfizetni, márpedig ideiglenes oltalom esetén is volt oltalom. ${ }^{62}$

Az illetékek közül a felfolyamodásért fizetendö illeték a felfolyamodás sikere esetén visszautalható volt, azonban ez a szabály a fellebbezésre nem vonatkozott. Viszszautalta továbbá a bíróság a bejelentő által megfizetett bejelentési díjat akkor is, ha a bejelentő szegénységi jogot nyert. ${ }^{63}$

\subsection{Gyakorlatbavétel mint a feltalálót terhelö kötelezettség}

A díjfizetés mellett a feltaláló másik kötelezettsége a gyakorlatbavétel volt. Gazdaságpolitikai megközelítésben ugyanis a szabadalom az ipar szabadságának kor-

55 E szabályozás oka a PUE hágai módosításának való megfelelés volt, mely 5. cikk (2) bekezdése elöírta a tagállamok számára, hogy az esedékességet követően 6 hónapos póthatáridőt kell biztosítani a szabadalmas részére, vagy pedig lehetővé kell tenni a dífizetés elmulasztása miatt hatályukat vesztett szabadalmak „felelevenítését”. A magyar jogalkotó az utóbbi eset elkerülése végett döntött a 6 hónapos póthatáridő pótdíjjal egybekötött bevezetése mellett.

56 E kivétel azonban az első évi dijakra nem vonatkozott.

57 1932:XVII. tc. 10. §.

${ }^{58}$ Azonban megsemmisítés esetén annak ex tunc hatálya ellenére sem jártak vissza a már korábban esedékessé vált és befizetett évi dijak.

59 Érdekes, hogy a szabályozási mintául szolgáló német szabadalmi törvény mind a két esetben lehetővé tette a szabadalmi díj visszafizetését.

60 HaRAusz Gyula: i. m., 422.

61 „Az évi dijak évenként elöre esedékesek és vagy évenként, vagy több évre, vagy végre mind a 15 évre lefizethetök."

62 Továbbá meg kell jegyezni, hogy a közzétett bejelentés visszavonásának egyik gyakori indoka épp az első évi szabadalmi dij meg nem fizetése volt.

63 A polgári perrendtartásból ismeretes intézményt a szabadalmi jogba az 1932. évi novella honosította meg. A szegénységi jog értelmében, aki vagyontalanságát szegénységi bizonyítvánnyal igazolja, vagy kimutatja, hogy napi keresetre van utalva, annak [törvényben] meghatározott külön dijakat hitelezni lehet, és ha a szabadalom a negyedik év kezdete elött megszünik, teljesen el is lehet engedni. 
látozása az iparfejlesztés érdekében. Ebben a megközelítésben a szabadalom egy állami beavatkozás, amellyel az állam nem tulajdonjogot adott ugyan, de kizárólagosságot a találmány előállítására és értékesítésére. ${ }^{64} \mathrm{E}$ kizárólagosság egyik célja a hazai ipar kielégítése volt, amelyet, ha a feltaláló nem elégített ki, akkor a kizárólagosság által okozott piaci korlátozás nemhogy az ipari fejlődést nem szolgálta, de egyenesen piackorlátozó hatású volt. Az oltalom kettős arculatából adódott, hogy a szabadalmi jog a feltalálói erőfeszítések anyagai értékeléseként kizárólag az oltalmas részére engedte meg a találmány előállítását és forgalomba hozatalát, azonban e jogosultság egyben kötelezettség is volt. A kizárólagosság birtokában ugyanis már nem a szabadalmas döntésén múlt, hogy hasznosítja-e találmányát vagy sem. ${ }^{65}$ Hiszen a kizárólagos jogot nem azért biztosította az állam, hogy azt ne gyakorolják, hanem éppen azért, hogy azt egy bizonyos személy, és csakis ő gyakorolhassa, méghozzá az ipar valamely ágának fejlesztése céljából. Amennyiben ez nem így lett volna, az a szabadalmi oltalom tartalmát üresítette volna ki, amely e kötelezettség nélkül nem más, mint egy a piacot bénító monopólium. A magyar szabadalmi törvényhez füzött miniszteri indokolásból is ez olvasható ki: „a szabadalmi oltalom kizárólag a honi ipar támogatása szempontjából adatván, a törvény követelheti, hogy a magyar szabadalom által védett tárgy vagy eljárás a magyar korona területén gyártassék, illetve alkalmaztassék". ${ }^{6}$

Így a szabadalmi törvények az oltalomban részesített feltalálókat arra ösztönzik, hogy a lehető legrövidebb időn belül „vegyék gyakorlatba” találmányukat, hiszen a kizárólagosság folytán a feltalálónak nemcsak joga, hanem kötelessége is a hazai ipar kielégítése. Ennek megvalósítását szolgálja a feltalálót terhelő gyakorlatba vételi kötelezettség is. ${ }^{67}$

A gyakorlatba vételre rendelkezésre álló határidő meghatározása kulcsfontosságú lehet, hiszen ha ez túlságosan rövid, illetve szigorú, akkor a kizárólagos jog illuzórikussá válhat, ha viszont túlságosan megengedő, akkor az a nemzeti ipar azon érdekét sértheti, hogy a gyakorlás valóságos és olyan legyen, amely az iparfejlesztést ténylegesen előmozdítani képes. Mindezek alapján megállapítható, hogy a gyakorlási kényszer kapcsán a törvényhozónak olyan megoldásra kell törekednie, mely az

64 MAYER Géza: A szabadalmak gyakorlási kényszerének kérdéséhez, Szabadalmi Közlöny, 32. évfolyam (1927), 8. szám, 123.

65 Schuster Rudolf: A kényszerengedély kérdéséhez a szabadalmi ügyben, Ügyvédek Lapja, 31. évfolyam (1916), 52. szám, 2.

66 1895:XXXVII. tc. 20. §-ához füzött miniszteri indokolás. 1895:XXXVII. tc. 20. §-ához füzött miniszteri indokolás. Képviselőházi Irományok, 1892. év XXIII. köt. 741. szám, 104.

67 Anglia és az USA kivételével az államok záros határidőhöz kötötték a találmány gyakorlatbavételét, melynek elmulasztása - ha van lehetőség igazolástól függően - visszavonással vagy megsemmisítéssel járt. E határidő 1-4 év között mozgott, s a gyakorlatbavétel terjedelmétől, illetve az igazolás lehetőségétől függően a részletszabályok eltérőek voltak. A teljesség igénye nélkül a legjelentősebb európai államok a következő megoldásokat alkalmazták. Franciaországban, ha a szabadalom külföldön gyakorlatba vétetett, akkor ezen időponttól számított egy éven belül belföldön is gyakorlatba kellett venni. Olaszországban öt évnél rövidebb időre adott szabadalmak esetén egy éven belül, ennél hosszabb időre adott szabadalmak esetén két éven belül gyakorlatba kellett venni. Portugáliában és Spanyolországban az oltalom elnyerésétől számított két éven belül, míg Németországban három éven belül gyakorlatba kellett venni. Bár az angol szabadalmi jog kezdetben nem ismerte a gyakorlatbavételi kötelezettséget, a szabadalom visszavonható volt, ha az az angol alattvalókra nézve káros vagy alkalmatlan volt. 
ipar és a feltaláló érdekei között a helyes középúton marad. ${ }^{68}$ Véleményem szerint e helyes középutat három kritérium határozhatja meg. Egyrészt a gyakorlatbavételre nyitva álló határidő, másrészt a gyakorlatbavétel terjedelme, harmadrészt az elmulasztásához füződő jogkövetkezmény.

A magyar szabadalmi törvény az oltalom elnyerésétöl számított három évet adott a feltalálónak arra, hogy találmányát belföldön gyakorlatba vegye. ${ }^{69} \mathrm{Ez}$ a megoldás teljes mértékben megfelelt az európai gyakorlatnak, és az alkalmazás során is praktikusnak bizonyult. Az 1895:XXXVII. törvénycikket megelözően az 1852-es pátens is ismerte ezt a jogintézményt, de mindössze egyetlen évet biztosított a szabadalmas számára. ${ }^{70}$ Ez semmiképpen sem volt elegendő, hiszen léteztek olyan nagyszabású találmányok, amelyek megvalósítása olyan komoly előmunkálatokat igényelt, ami eleve kizárta, hogy a találmányt e rövid idő alatt akár egyetlenegy példányban is előállítsák.

Ami a gyakorlatbavétel terjedelmét illette, az 1852-es pátens rendkívül szigorú követelményeket támasztott, hiszen elvárta, hogy a találmány az első év végére a szabadalmi leírás alapján legalább egy példányban elő legyen állítva. Szabadalmi törvényünk ehhez képest enyhébb kritériumokat támasztott, mert megelégedett azzal, hogy a feltaláló „a hazai és saját ipari és vagyoni viszonyaihoz képest”1 mindent megtett a gyakorlatbavétel foganatosítása iránt. Ebböl következik, hogy a szabadalom tulajdonosát nem lehetett arra kötelezni, hogy a belföldi szükségleteket teljes mértékben kielégítse, ugyanakkor e gyakorlatbavételnek valóságosnak és ténylegesnek kellett lennie, amelyröl minden esetben - a konkrét körülményeket figyelembe véve - a Szabadalmi Bíróság döntött.

A kifejtettek értelmében tehát a gyakorlatbavételi kötelezettség valamennyi modern szabadalmi rendszer részét képezte,,$^{72} \mathrm{~s}$ így az első szabadalmi törvényünk is átvette ezen intézményt azzal a következménnyel, hogy a kötelezettség nem megfelelő teljesítése a szabadalom megvonásával járt. ${ }^{73}$

68 DeUtsch Izidor: A szabadalomból folyó jogviszonyok, i. m., 32.

69 1895:XXXVII. tc. 20. §: „A szabadalom egészben vagy részben megvonható, ha a szabadalom tulajdonosa elmulasztotta találmányát a magyar korona országai területén lényegileg és kellö terjedelemben gyakorlatba venni, vagy ezen gyakorlatba-vételt igazolatlanul - szünetelés által - félbeszakitotta, vagy legalább a hazai és saját viszonyaihoz képest mindent meg nem tett, mi ezen gyakorlatba-vétel foganatositására és folytatására szükséges. Ezen megvonás rendszerint nem mondható ki előbb, mint a szabadalom megadásának kihirdetésétôl számitandó három év elmultával."

70 Az 1852. évi pátens 29. § (2). bek. a) pontja értelmében „a szabadalmak érvényüket vesztik megszünés által; ilyen akkor áll be, ha a szabadalmazott a szabadalmi okirat kiállitásától számított legfeljebb egy év alatt találmánya, fölfedezése vagy javitása gyakorlását belföldön nem kezdte meg”.

71 Az 1895:XXXVII. tc. 20. §-ához füzött miniszteri indokolás. Képviselöházi Irományok, 1892. év XXIII. köt. 741. szám, 104.

72 Érdekes azonban, hogy a gyakorlatbavételi kötelezettségnek, az európai államokhoz hasonló és szigorú megfogalmazása a 19. századi angol és amerikai szabadalmi törvényekben nem lelhető fel. Vö. DEUTSCH Izidor: A szabadalmi törvényjavaslat, i. m., 210.

73 1895:XXXVII. tc. 20. § (1) bek. (vö. 69. sz. lábjegyzettel). 


\section{4. Összegző gondolatok}

A modern jogrendszerekben a szabadalmi oltalom célja a nemzeti ipar fejlesztésén túl a feltalálói tevékenység elösegítése. Az intézmény kettőssége figyelhető meg a feltaláló jogállásának törvényi szabályozásában is. A feltalálói minőség elismerése a feltaláló olyan alapvető érdeke, amelyet a jognak minden eszközzel támogatni kell, így ennek védelme érdekében az általános magánjogi intézmények is felhívhatóak voltak. Figyelembe véve azonban a szabadalmak piacra gyakorolt hatását, nyilvánvaló, hogy az oltalom komoly anyagi következményekkel jár. A feltaláló jogállására vonatkozó szabályozásban is ez figyelhető meg. Az oltalom által biztosított kizárólagosság értelmében egyedül a szabadalmas jogosult a találmányt iparszerủen előállítani, használatba venni vagy arról rendelkezni. Önmagában ez a kizárólagosság monopolhelyzetet teremtene, amennyiben a jogosulton múlna, hogy azt ténylegesen gyakorolja vagy sem. Ebből adódóan a dífizetésen túl az oltalmas egyetlen kötelezettsége a találmány hazai szükségletet kielégítő módon történő gyakorlatbavétele. Így a feltaláló részére biztosított legerőteljesebb vagyoni jog egyben kötelezettség is, melyek harmonikus együttléte biztosítja a szabadalmi jog valódi iparfejlesztő szerepét.

Az első szabadalmi törvényünk is ezt a jogalkotási logikát követte. Bár a törvény a feltaláló vagyoni jogait sokszor pontatlanul vagy félreérthető módon szabályozta, de a későbbi évtizedek jogalkalmazása lehetővé tette a törvény valódi célkitüzéseinek megvalósulását, s egyúttal kijelölte a későbbi jogfejlődés irányát is.

\section{Abstract}

The first Hungarian Act on Patents was adopted in 1895. The study examines the regulation of the inventor's legal status in this act and the problems the legislature had to solve. In the first part of the study the inventor's rights are described regarding the inventor's personal and valuable rights and interests. By the beginning of the 20th century license became the most important valuable right and interest, although its regulation could not be found in any act. In fact, a decision of the Patent Court in 1928 declared the regulation of leasehold valid, which raised greater and greater difficulties in legal application from the second half of the 20th century. The second part of the study examines the inventor's obligation of payment and functioning. The latter is one of the special features of the intellectual property system which is regulated by the Industrial Property Union. 